УДК 004.05:656.2 (477)

DOI: https://doi.org/10.37320/2415-3583/20.6

Каличева Н.С.

доктор економічних наук, професор

Український державний університет залізничного транспорту

ORCID: https://orcid.org/0000-0003-3523-1071

Масан В.В.

аспірант

Український державний університет залізничного транспорту

Сафронов O.E.

магістр

Український державний університет залізничного транспорту

\title{
ХМАРНІ ТЕХНОЛОГІЇ ЯК ІНСТРУМЕНТ ЗАБЕЗПЕЧЕННЯ КОНКУРЕНТНОГО РОЗВИТКУ ПІДПРИЕМСТВ ЗАЛІЗНИЧНОГО ТРАНСПОРТУ
}

Підприємства сфери транспорту є основою забезпечення ефективності всього виробничого комплексу краӥни. Від перспектив їхнього розвитку залежить успішне функиіонування народногосподарського комплексу держави. У дослідженні зазначено, щзо забезпечення ефективного конкурентного розвитку в сучасному світі неможливе без використання новітніх інформачійних технологій. Одним із таких заходів є застосування хмарних технологій. Хмарні технологї-ие засоби збереження та доступу до даних шляхом використання системи Інтернет. Вони необхідні для вирішення значної кількості проблем, пов'язаних з оптимізацією функціонування та конкурентоспроможністю підприємств залізничного транспорту. У статті розкрито переваги та недоліки використання на підприємствах залізничного транспорту сучасних інформаційних технологій. Розглянуто основні вимоги до хмарних сервісів для сфери транспорту.

Ключові слова: підприємства залізничного транспорту, інформачійні технологї̈, хмарні сервіси, конкурентоспроможність, ефективність, управління, оптимізація витрат.

Постановка проблеми. Сучасний розвиток підприємств залізничного транспорту має тісний зв'язок із широким запровадженням нових інформаційних технологій, швидким розвитком засобів супутникової навігації, електронних картографічних інформаційних і навігаційних систем тощо. Усе це призводить до необхідності змінювати підходи до застосування інформаційних технологій. Зокрема, однією 3 інформаційних технологій, яка активно запроваджується на підприємствах і в орга- 
нізаціях, є платформи для хмарного збереження баз даних.

Аналіз останніх досліджень і публікацій. Питання розвитку підприємств залізничного транспорту в умовах цифровізації $\epsilon$ досить актуальними. Серед основних дослідників даної проблеми можна виділити Л.С. Головкову, В.Л. Диканя, В.В. Компанієць, В.О. Овчиннікову, І.В. Токмакову, К.О. Січкаренко та ін. [1-6]. У їхніх дослідженнях досить детально розкрито вплив інформаційних технологій на господарську діяльність галузі. Але реалії сьогодення призводять до того, що підприємства сфери транспорту для забезпечення конкурентного розвитку повинні приймати нестандартні рішення та використовувати сучасні інноваційні технології. Зокрема, особливої актуальності набуває питання використання хмарних технологій, що дасть змогу вирішувати завдання, пов'язані з раціональним управлінням у галузі, підвищенням ефективності транспортного обслуговування, забезпеченням безпеки перевізного процесу, зменшенням витрат і т. д.

Мета статті полягає у визначенні ролі хмарних технологій у забезпеченні конкурентного розвитку підприємств залізничного транспорту.

Виклад основного матеріалу. Нині у світі відбувається повна віртуалізація ділового життя, що призводить до необхідності суб'єктам господарювання активно використовувати нові інформаційні технології.

Для підприємств залізничного транспорту, в діяльності яких нині відбуваються значні цифрові трансформації, застосування інформаційних технологій дає можливості [7]:

- сформувати сучасні управлінські технології із застосуванням ситуаційних математичних моделей, моніторингових прогнозних систем перевізного процесу, програм реального розвитку логістики, формування i використання динамічних експлуатаційних резервів пропускної і провізної спроможності залізничних ліній;

- використовувати інтелектуальні автоматизовані системи управління;

- створювати системи управління для інтелектуального рухомого складу та відповідної інфраструктури на основі самодіаг- ностики інфраструктури і рухомого складу, що забезпечить передачу оперативної інформації про технічний стан, залишкові ресурси, доцільність зміни режиму роботи і ремонтного циклу або необхідність виведення $з$ експлуатації, скорочення питомого енергоспоживання на тягу і витрат на експлуатацію;

- забезпечувати безпеку, екологічність та надійність перевезень.

Головним завданням цифрової трансформації підприємств залізничного транспорту $€$ забезпечення гнучкості й ефективності виконання бізнес-процесів, що дасть змогу підвищити рівень конкурентоспроможності на ринку в сучасних умовах господарювання [8].

Застосування хмарних технологій як однієї 3 передових технологій у цифровому суспільстві щодо управління та обліку інформації дасть змогу підприємствам сфери транспорту отримати такі переваги:

- економічність, а саме зниження витрат на створення центрів обробки даних, закупівлю обладнання та програм, утримання відповідних фахівців і т. д.;

- мобільність, а саме можливість безперешкодного отримання необхідної інформації з будь-якої точки доступу до Інтернету;

- еластичність, а саме спроможність вносити зміни до корпоративної IT-інфраструктури залежно від нагальних потреб;

- доступність;

- самообслуговування;

-збереженість інформації без додаткового резервування і т. д.

Необхідно зазначити, що залізничний транспорт і його підприємства є основою національної безпеки країни, тож забезпечення безпеки інформаційних сервісів має бути одним із першочергових завдань.

Основними ризиками та викликами застосування хмарних технологій для підприємств залізничного транспорту є:

-кіберзагрози, а саме атаки, перехоплення трафіку і т. д.;

- атаки на системи управління;

- наявність постійного стабільного з'єднання з Інтернетом;

- значна залежність від постачальника технологій; 
- DDOS-атаки, тобто напад на систему 3 метою зробити недоступними комп'ютерні ресурси.

Та все-таки, незважаючи на недоліки, транспортні підприємства, які прагнуть бути конкурентоспроможними на ринку, використовують у своїй діяльності хмарні технології, найбільш орієнтовані до споживачів. Основними з них є [9]:

- електронна авіанакладна (е-AWB) (стандартизована цифрова версія паперових накладних, котра супроводжує вантаж в дорозі);

- великі дані та машинне навчання (під час застосування Big data відбувається зміна формування бізнес-моделей підприємства шляхом спрощення прогнозів попиту, оптимізації маршрутів, управління ризиками та прогнозної аналітики);

- хмарна логістика (сервіси Shipwire i Freightly надають хмарні системи управління транспортом у режимі реального часу, мають змогу охопити всі логістичні процеси - від закупівель до виставлення рахунків, що значно спрощує та здешевлює процес);

- Інтернет речей (IоT) (наявність «розумних» вантажівок дасть змогу збирати дані про переміщення і час простою для динамічного планування маршруту і максимізації використання парку рухомого складу, що призведе до зниження витрат на технічне обслуговування);

- блокчейн (схеми відстеження товару, засновані на блокчейні, забезпечують повну прозорість і відстеження вантажів по всьому маршруту проходження).

Для підприємств залізничного транспорту актуальним $є$ питання вибору хмарних технологій як одного $з$ основних чинників забезпечення їхнього конкурентного розвитку. Під час вибору необхідного сервісу перше, на що необхідно звернути увагу, - це оптимальність у співвідношенні «ціна - якість», тобто на наявність відповідних опцій за прийнятну ціну. А під час оцінювання реальної роботи конкретної технологічної платформи необхідно:

- оцінити гнучкість сервісу та спроможність його доопрацювання під потреби залізничного транспорту;
- проаналізувати досвід інших компаній, які вже запровадили такі технології;

- виконати моделювання «як було» та «що отримаємо», щоб у реальних умовах оцінити роботу сервісу та отримати розрахунок планової економії з використанням конкретних даних підприємства;

- звернути увагу, за рахунок яких показників (основних та додаткових) відбувається зниження вартості перевізної робити на т/км як основного показника роботи транспортної галузі.

Також для того щоб хмарні технології ефективно працювали, підприємствам залізничного транспорту необхідно налагодити роботу шляхом вірного геопозиціонування точок доставки, точно вносити всю довідкову інформацію, яка має вплив на розрахунок маршруту та оптимальність вибору рухомого складу, а саме:

- режими роботи;

- час на навантаження, вивантаження та перевантаження;

- вантажопідйомність рухомого складу;

- швидкість руху;

- тривалість робочого дня і т. д.

Висновки. Таким чином, запровадження хмарних технологій у діяльність підприємств залізничного транспорту дасть змогу суттєво збільшити якість транспортного обслуговування та підвищити їхню конкурентоспроможність, адже гнучкість віртуального середовища дасть змогу суттєво змінити характер діяльності, підвищити надійність, доступність, безпеку тощо за рахунок оптимізації витрат, збільшення швидкості обслуговування, оптимізації маршрутів руху, поліпшення взаємодії різних видів транспорту і т. д.

Широке запровадження хмарних сервісів дасть змогу підвищити ефективність роботи підприємств залізничного транспорту, забезпечить високий рівень задоволеності споживачів і, відповідно, сприятиме їхньому конкурентному розвитку.

Щодо подальших досліджень цього питання, то необхідно більш детально вивчати реальність та ефективність запровадження конкретних хмарних технологій у залізничній галузі. 


\section{Список використаних джерел:}

1. Головкова Л.С., Ляшко Д.Ю. Тенденції та фактори впливу на процес залізничних перевезень в Україні. Інфраструктура ринку. 2017. Вип. 8. С. 26-31.

2. Дикань В.Л., Обруч Г.В. Управління реалізацією спільних інвестиційних проєктів за участю підприємств залізничного транспорту в умовах цифровізації. Вісник економіки транспорту і промисловості. 2020. № 69. С. 9-21.

3. Компаниец В.В. Концептуальный анализ перспектив цифровизации экономики и железнодорожного транспорта. Вісник економіки транспорту і промисловості. 2018. № 62. С. 197-200.

4. Овчиннікова В.О., Торопова В.І. Розвиток підприємств залізничного транспорту України в умовах цифровізації. Вісник економіки транспорту і промисловості. 2019. № 68. С. 175-181.

5. Січкаренко К.О. Вплив цифровізації економіки на розвиток транспортної галузі. Причорноморські економічні студї. 2019. Вип. 38-1. С. 76-79.

6. Цифрова трансформація залізничного транспорту як фактор його інноваційного розвитку / I.В. Токмакова та ін. Вісник економіки транспорту і промисловості. 2019. № 68. С. 125-134.

7. Каличева Н.Є. Вплив інформаційних технологій на ефективність функціонування вітчизняної транспортно-логістичної системи в сучасних умовах. Актуальні проблеми та напрями розвитку потенціалу соціально-економічних систем в умовах конкуренції : монографія / за заг. ред. Л.Л. Калініченко. Харків : ТОВ «У справі», 2017. С. 201-210.

8. Бараш Ю.С., Чаркіна. Т.Ю. Управління конкурентоспроможністю залізничних пасажирських перевезень : монографія. Дніпро : ДНУЗТ, 2015. 184 с.

9. П'ять ключових технологій для цифрової трансформації в логістиці. URL: https://www.everest.ua/pyat-klyuchovyh-tehnologij-dlya-czyfrovoyi-transformacziyi-v-logistyczi (дата звернення: 22.09.2021).

10. Каличева Н.Є. Забезпечення конкурентоспроможності підприємств залізничного транспорту (методологічні аспекти) : монографія. Харків : УкрДУЗТ, 2019. 391с.

\section{References:}

1. Holovkova L.S., Liashko D.Iu. (2017) Tendentsii ta faktory vplyvu na protses zaliznychnykh perevezen $\mathrm{v}$ Ukraini. [Trends and factors influencing the process of railway transportation in Ukraine]. Market infrastructure, vol. 8, pp. 26-31.

2. Dykan V.L., Obruch H.V. (2020) Upravlinnia realizatsiieiu spilnykh investytsiinykh proektiv za uchastiu pidpryiemstv zaliznychnoho transportu $\mathrm{v}$ umovakh tsyfrovizatsii [Management of implementation of joint investment projects with the participation of railway transport enterprises in the conditions of digitalization]. Bulletin of Transport Economics and Industry, no. 69, pp. 9-21.

3. Kompanyets V.V. (2018) Kontseptualnyi analyz perspektyv tsyfrovyzatsyy ekonomyky y zheleznodorozhnoho transporta [Conceptual analysis of prospects for digitalization of the economy and railway transport]. Bulletin of Transport Economics and Industry, no. 62, pp. 197-200.

4. Ovchynnikova V.O., Toropova V.I. (2019) Rozvytok pidpryiemstv zaliznychnoho transportu Ukrainy v umovakh tsyfrovizatsii [Development of Ukrainian railway transport enterprises in the conditions of digitalization]. Bulletin of Transport Economics and Industry, no. 68, pp. 175-181.

5. Sichkarenko K.O. (2019) Vplyv tsyfrovizatsii ekonomiky na rozvytok transportnoi haluzi [The impact of digitalization of the economy on the development of the transport industry]. Black Sea Economic Studies, vol. 38-1, pp. 76-79.

6. Tokmakova I.V., Cherednychenko O.Iu., Voitov I.M., Palamarchuk Ya.S. (2019) Tsyfrova transformatsiia zaliznychnoho transportu yak faktor yoho innovatsiinoho rozvytku [Digital transformation of railway transport as a factor of its innovative development]. Bulletin of Transport Economics and Industry, no. 68 , pp. $125-134$.

7. Kalycheva N.Ye. (2017) Vplyv informatsiinykh tekhnolohii na efektyvnist funktsionuvannia vitchyznianoi transportno-lohistychnoi systemy v suchasnykh umovakh. Aktualni problemy ta napriamy rozvytku potentsialu sotsialno-ekonomichnykh system $v$ umovakh konkurentsii: monohrafiia [Influence of information technologies on the efficiency of the domestic transport and logistics system in modern conditions. Actual problems and directions of development of potential of social and economic systems in the conditions of competition: monograph]. Kharkiv: FOP Panov AM Published. LLC "In the case". (in Ukrainian) 
8. Barash Ju.S., Charkina. T.Ju. (2015) Upravlinnja konkurentospromozhnistju zaliznychnykh pasazhyrsjkykh perevezenj: monoghrafija [Vanaging Competitiveness of Rail Passenger Transportation a monograph]. Dnipropetrovsjk: Dnepropetrovsk National University of Railway Transport. (in Ukrainian)

9. Piat kliuchovykh tekhnolohii dlia tsyfrovoi transformatsii v lohistytsi. [Five key technologies for digital transformation in logistics]. Available at: https://www.everest.ua/pyat-klyuchovyh-tehnologij-dlya-czyfrovoyi-transformacziyi-v-logistyczi (accessed 22 September 2021).

10. Kalycheva N.Je. (2019) Zabezpechennja konkurentospromozhnosti pidpryjemstv zaliznychnogho transportu (metodologhichni aspekty): monoghrafija [Ensuring competitiveness of railway enterprises (methodological aspects): a monograph]. Kharkiv: Ukrainian State University of Railway Transport. (in Ukrainian)

Kalicheva Natalia, Masan Vadim, Safronov Oleh Ukrainian State University of Railway Transport

\section{CLOUD TECHNOLOGIES AS A TOOL FOR ENSURING COMPETITIVE DEVELOPMENT OF RAILWAY TRANSPORT ENTERPRISES}

Currently, in the world there is a complete virtualization of business life, which leads to the need for businesses to actively use new information technologies. The main task of digital transformation of railway transport enterprises is to ensure flexibility and efficiency of business processes, which will increase the level of competitiveness in the market in modern business conditions. The issue of choosing cloud technologies as one of the main factors in ensuring their competitive development is relevant for railway transport enterprises. Cloud technologies are means of storing and accessing data using the Internet. They are needed to solve a significant number of problems related to the optimization of operation and competitiveness of railway transport enterprises. The use of cloud technologies, as one of the advanced technologies in the digital society for information management and accounting, will allow transport companies to gain the following benefits - efficiency, mobility, flexibility, accessibility, self-service, information safety without additional redundancy, etc. The introduction of cloud technologies in the activities of railway transport enterprises will significantly increase the quality of transport services and increase their competitiveness. After all, the flexibility of the virtual environment will significantly change the nature of activities, increase reliability, availability, security, etc. by optimizing costs, increasing service speed, optimizing traffic routes, improving the interaction of different modes of transport, etc. In order for cloud technologies to work effectively, railway transport companies need to establish work by correctly geo-positioning delivery points, accurately enter all reference information that affects the calculation of the route and the optimal choice of rolling stock, namely operating modes, time for loading, unloading and reloading, rolling capacity, speed, working day, etc. Widespread introduction of cloud services will increase the efficiency of railway transport enterprises, ensure a high level of consumer satisfaction, and accordingly - will promote their competitive development. Regarding further research on this issue, it is necessary to study in more detail the reality and effectiveness of the introduction of specific cloud technologies in the railway industry.

Key words: railway transport enterprises, information technologies, cloud services, competitiveness, efficiency, management, cost optimization.

JEL classification: M15, O32, O33, R41 